\title{
IMPACT OF THE LOCATIONS OF SMALL TOWNS IN MAZOVIA (POLAND) ON THEIR SOCIO-ECONOMIC STRUCTURE AND ON THEIR ROLE IN RELATION TO THE NEIGHBORING RURAL AREAS
}

\author{
Jerzy BAŃSKI, Konrad CZAPIEWSKI, Magdalena GÓRCZYŃSKA \\ Institute of Geography and Spatial Organization, Polish Academy of Sciences

\begin{abstract}
This paper centers on the smallest towns (with populations below 10000 inhabitants) in Mazovia region, Poland. What is mainly involved in the paper is an indicating of differences or regularities characterising the functional structures of small towns, and the roles they play in respect of the surrounding areas - in relation to their geographical location. The subjects of the detailed study were 10 localities in Mazovia: Serock, Radzymin, Ożarów Mazowiecki, Pilawa and Skaryszew - all located in the vicinity of a large agglomeration; and Łosice, Różan, Przysucha, Lipsko and Chorzele, in peripheral locations. Small peripheral towns have much more important functions to supply to the rural areas surrounding them than the agglomerated towns. Unfortunately, they are losing internal potential and they are characterised by unfavourable demographic processes. In turn, the small towns located within the wider surroundings of the agglomerations have been experiencing population growth.
\end{abstract}

Key Words: small towns, Mazovia, Poland, socio-economic structure, agglomeration, peripheries.

\section{Introduction}

Small towns represent an important element of the spatial and functional structure in each country. In Poland, they represent more than $70 \%$ of all urban areas and comprise roughly $20 \%$ of the population. Growth in the number of studies about small towns, particularly in geography discipline, is not therefore surprising. The main axis of research on small towns relates to demographic issues, the quality of life, and economic development. However, the bulk of the research centres on the functional structure of small centres, and the relationship between them and the surrounding rural areas (Elsasser 1998, Courtney and Errington 2000, Hinderink and Titus 2002, Duranton and Puga 2005, Heffner 2005, Rydza 2006). Studies indicate that small towns are local development centers, which focus on administrative, services and trade functions used by the inhabitants of the surrounding countryside.

Generally, the identification of the main functions of small towns is based on the analysis of the dominant sectors of the economy, or - more broadly - the role of the different socio-economic domains in the town's development. The studies of the functional structure of Polish towns by Jerczyński (1977) represent an example of the first type of research. Jerczyński (1977) distinguished ten functional types of towns by analysing employment in the three main sectors of the economy. At that time, the prevailing types were: industrial, industrial-services, as well as services-industrial. A great number of industrial towns resulted from the post-war policy of industrialisation and urban development based on industrial investment. Kachniarz (1987) divided towns of less than 20000 inhabitants into 23 groups that varied in terms of functional structure, administrative status and number of residents. He argued that those small towns and municipal centres would primary deliver services to the local population and to agriculture, as well as developing light industry and crafts. However, later studies carried out by Szymańska 
and Grzelak-Kostulska (2005) failed to confirm this scenario, revealing that - since the transformation - the number of small towns performing service functions had increased, especially in central areas (Lamprecht 2008), to the detriment of industrial and agricultural towns.

The transformation has also affected the economic structure of small towns, notably in terms of numbers and types of new private enterprises that have flourished. Adopting the example of small towns in the Silesia region, Zuzańska-Zyśko (2005) argued that the 1990s brought a major increase in the number of new enterprises servicing agricultural areas, while the rate of growth characterising these in specialised towns (e.g. in mining, or with a tourist function) was much weaker. As recently as in 1999, roughly half of the population of small towns in Silesia was employed in manufacturing, trade and repair, and in mining (Zuzańska-Zyśko 2005). However, by 2005, employment in services in the small towns of the Silesia and Wielkopolska regions had grown to $28 \%$ (Konecka-Szydłowska et al. 2010).

The functional specialisation of small towns was also explored using principal component and discriminant analysis based on variables relating to social, economic and demographic features (Lin 1993). This was further investigated in two categories of small towns in China, with regard to their status and administrative position. The study of Welsh small and market towns revealed that their function as local poles of employment varies with regard to their location (Woods et al. 2007). Small towns that are significant administrative centres in more remote locations have the highest ratios of jobs to working residents, whereas the lowest ratios correspond to the small towns close to other larger urban localities. In line with functions, services offered and employment opportunities, six ideal-type models of small and market towns were distinguished: sub-regional centres (discharging higher-order service functions to the benefit of extensive rural areas), anchor towns (providing commercial, social and administrative functions in respect of a rural district), island towns (located close to larger urban centres but capable of maintaining their independence in terms of employment and services), doughnut towns (with quite a strong hinterland providing additional services and employment), satellite towns (close to larger urban centres and dependent on them) and niche towns (creating new and specialised attractions to take the place of previous functions that had declined).

By considering economic structure and level of independence vis-à-vis the large city of Izmir (Turkey), four functional types of small satellite towns were identified: towns with a predominance of the residential function (located under the immediate influence of a metropolis); towns producing for the main city; towns that are quite independent and 'image bearing' (as tourist centres); and rural centres maintaining an intermediate position between rural areas and the metropolis (Montabone 2013). However, despite these nuances, all the small towns remained under a certain influence of Izmir, while also contributing to its development.

In the case of the Kaluga region (Russia), the functions of small towns were explored in the light of their locations, and on the basis of quantitative data and information obtained in interviews with experts (Savoskul et al. 2014). The authors argued that a location in close proximity to Moscow enables permits of industrial or recreational functions to develop in small towns. On the other hand, a location on the fringes of the region, in only poor connection with the capital city ensures stagnation, and hence the retention of historically developed industrial and transport functions, given the lack of new impulses for a change of structure. Finally, the small towns that were once centres serving agriculture had lost their key function due to the crisis in that sector, commencing instead with the provision of at best simple administrative and urban functions.

In line with locations in the Moravian region (Czech Republic), Vaishar and Zapletalová (2009) distinguished three sub-types of small town: (1) in the hinterlands of large cities, (2) in lowlands 
with good accessibility to larger cities and (3) on the periphery. In line with their specific locations, small towns in the vicinity of large cities are seen to lose their central functions, those well connected with other urban centres strive to specialise as regards functions, while those located in distant areas become centres of their hinterland. Moreover, the population growth is greater in suburbanised small towns than in those located in more distant areas, while the set of functions served is also a function of the size of the small town (Vaishar et al. 2015).

A number of studies have focused on case-study towns and the evolution of their functions over time, also providing interesting evidence in this way. Small towns in the vicinity of larger urban centres may attempt to preserve their identity and apply smart growth goals. The example of Davidson (United States) shows that the development of retailing and services for residents and of industrial jobs that benefit the entire region can combine with the elaboration of innovative tools by which to manage local growth to support dynamic local development successfully (Lambe 2008). Indeed, employment in industry and construction still plays a key role in small satellite towns in Poland or France, despite the growing number of economic units that operate in services (Kwiatek-Soltys et al. 2014). Such a functional structure still produces positive side effects, e.g. the development of cooperating companies in different domains. Moreover, where the economies of small towns are concerned, it is often more beneficial to host companies (e.g. in industry) occupying larger plots, given the higher revenues ensuing through the property taxes paid by companies. On the other hand, the small town of Farmville (United States) that was previously the centre of the national tobacco industry managed to diversify its economy after the traditional industry declined (Lambe 2008). First, a local strategy based on cooperation between public and private sector leaders entailed strong support being given to existing businesses, which created more than $80 \%$ of the new jobs and were responsible for a majority of the new investment. Second, Farmville focused on an intensive branding and marketing campaign to attract new residents and businesses. Finally, a pro-growth coalition created by local government became a key player in the development of Chengguan Zhen county (China), integrating the interests of government officials, state-run work-units and developers (Han 2010).

These few examples illustrate that, although the role of small towns depends to a certain extent on their position with regard to larger cities (ESPON 2006), an accurately conceived local strategy may result in positive changes of position in the local functional structure. Unfortunately, in recent years in Poland, the regional development policy focuses on metropolitan areas and big cities. In contrast, small towns are regarded rather as marginal issues. However, polycentric development, which is one of the paradigms of the current regional development policy, should take into account all elements of the settlement structure. For example, in the region of Mazovia, a medium-sized and smaller cities come together to form a relatively evenly distributed network of cities. This kind of spatial distribution may contribute to the gradual development of these cities, as the entirety performs a variety of local functions and even supra-local functions in some parts of the region where there are located "weak" subregional centres (Bański and Czapiewski 2015).

Although previous findings underlined how location in regard to a large city is crucial in shaping the functional structure of small towns, other groups of factors have also been identified. Satterthwaite and Tacoli (2003), for example, argued that small urban centres support regional development in four ways: as centres of demand for agricultural production, as centres for production and the distribution of goods to surrounding rural areas, as local job centres and as places attracting rural migration. They suggested that these roles are dependent on the specific context in which the town is located, and thus in regard to: land-owning structures, the quality of transport and communications and structural conditions at the international, national and local levels (Satterthwaite and Tacoli 2003). On the other hand, Lamprecht (2008) claimed that the functional transformation touching industrial sites in small towns is a function of former land use, accessibility (both in terms of transport and regulated land ownership) and the subjective 
value of the land.

Notwithstanding the various findings detailed above, the work detailed in this paper has sought to analyse the functional structure of small towns, through an exploration of the way in which territorial context affects that structure. What is mainly involved here is an indicating of differences or regularities characterising the functional structures of small towns, and the roles they play in respect of the surrounding areas - in relation to their geographical location.

Small towns and rural areas in Poland have undergone significant changes since 1989. First, suburban areas of major cities have experienced rapid economic development (Bański 2009). Second, financial support from the European Union funds has resulted in improved technical and transport infrastructure in rural areas. Third, a number of new investments have occurred in the wake of the near-instant collapse of the State Farms. Fourth, such features as civic society and social and economic activity have gathered strength among the inhabitants of both urban and rural areas.

In fact, the above are only selected examples of changes resulting from the transformation in Poland. They also had an impact in shaping new functions in the towns of the Mazowieckie (Mazovia) province-region or voivodeship. Thus, the second goal of the work presented in this paper has been to provide evidence on the directions of changes in the functional structure of selected towns in the voivodeship over the past three decades. We have thus sought to address a question regarding post -1989 changes in the functional structure of small towns as this relates to their location.

\section{Methodology}

Mazovia is a classic example of a highly polarised region given the presence of the principal urban centre (Bański and Czapiewski 2015). Warsaw far outweighs other cities in terms of socio-economic functions and demographic potential. The social, economic and cultural pressure exerted by the Warsaw agglomeration is manifested by signs of implosion and it weakens the opportunities for development in the other towns. An example of this phenomenon is provided by the stagnation or regression of demographic sub-regional cities (Radom, Płock, Siedlce, Ciechanów and Ostrołęka). Moreover, due to the last administrative reform, the sub-centres lost their status as capitals of voivodeships; and this also affected their positions negatively. This urban network is complemented by district towns and other, generally-smaller centres.

Among 86 urban localities within the Mazowieckie voivodeship, three of them are classified as major cites (Warszawa, Radom and Płock), 22 as medium-sized cities, and 61 as small towns. This paper is focused on the smallest 37 towns which belong to the latter group, each with a population size of less than 10000 inhabitants (Table 1).

The smallest towns (with populations below 10000 inhabitants) are not distributed evenly, but they are rather concentrated in the central part of the region, with the fewest on Warsaw's northern outskirts, and in a wide zone between the capital and Radom. In the communist period, the industrial function was of relatively major importance in the small towns. However, from the very beginning of the transformation, the number of jobs in industry declined dramatically. Figures for the percentages of enterprises operating in industry and construction fell in almost all small towns, and Mazovia proved to be no exception to that trend. The most major losses concerned the smallest centres, making a major contribution to economic regression among the latter. Today, the structure characterising employment in small towns is dominated by non-market services together with industry and market services. The greater importance of non-market services is mainly found in towns located at greater distances from 
Impact of the Locations of Small Towns in Mazovia (Poland) on their Socio-Economic Structure and on their Role in Relation to the Neighboring Rural Areas

the major urban centres. This is confirmed by an analysis of the participation of economic entities operating in industry and construction.

Size structure characterising towns and cities in the Mazovia region (2015)

\begin{tabular}{|l|r|r|r|}
\hline Size class (people) & Number of towns/cities & Population & \multicolumn{1}{|c|}{ Area $\left(\mathrm{km}^{2}\right)$} \\
\hline More than 100,000 & 3 & $2,068,955$ & 717 \\
$50-100,000$ & 4 & 240,431 & 94 \\
$20-50,000$ & 18 & 542,718 & 385 \\
$10-20,000$ & 24 & 349,473 & 497 \\
$5-10,000$ & 10 & 104,190 & 124 \\
less than 5,000 & 27 & 80,005 & 348 \\
\hline
\end{tabular}

Source: Central Statistical Office, Poland.

The subjects of the detailed study were two types of localities - central and peripheral. Peripherality is a very general phenomenon and despite many attempts to simplify its definition, it is not possible to cover all its dimensions by a single indicator. When reflecting on a wide range of scientific papers focused on peripherality (Leimgruber 1994, Schmidt 1998, Máliková and Spišiak 2013), it is possible to distinguish two main groups of approaches to the research of this phenomenon: the objective and the subjective dimension.

Using measures of spatial accessibility, distance and population density, Novotny et al. (2015) designated core and peripheral areas. To make the resulting values of different indices comparable, they were classified into four peripheral zones of different intensity of "peripherality", from A to D, and one as non-peripheral zone. Zone A has been defined as the area with the most significant values of a given index associated with peripheral areas. Using this division in our studies for detailed analyses (Fig. 1), there were selected five small cities in the vicinity of large agglomeration (Serock, Radzymin, Ożarów Mazowiecki, Pilawa and Skaryszew) and five small towns located in the peripheries (Łosice, Różan, Przysucha, Lipsko and Chorzele).

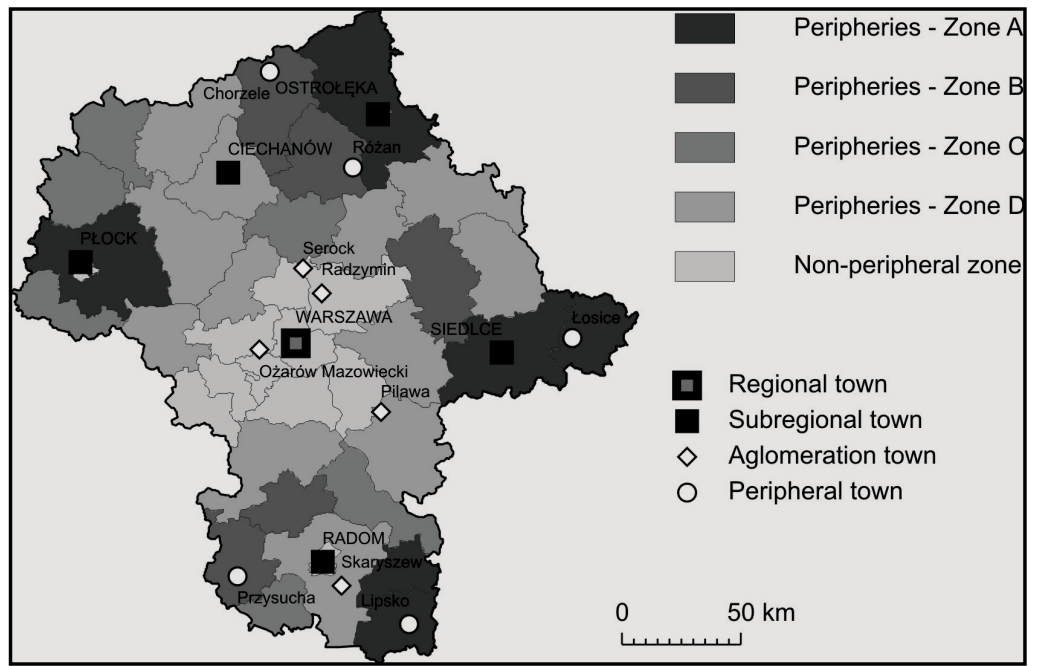

Fig. 1 - Level of peripherality and location of small towns selected for detailed study Source: own research 
Statistical analysis is based on data from the Central Statistical Office and the research conducted within the project Polycentric development of Mazovia region for the Mazovian Office for Regional Planning. Some conclusions are the results of the interpretation of social investigations (interviews and questionnaires) made in this project.

\section{Results and Discussion}

The two groups of town analysed - dubbed agglomerated and peripheral for convenience - are rather small in terms of population size (Table 2). Each is the main centre of a gmina (local-authority area) assigned to the rural-urban category ${ }^{1)}$. Beyond that, Łosice, Lipsko and Przysucha are all centres of administration at the next (county) level of the poviat $t^{2}$. Four of the agglomerated towns (Pilawa, Serock, Radzymin and Ożarów Mazowiecki) are in the immediate vicinity of the capital of region and state alike, i.e. Warsaw. For its part, Skaryszew is close to the important sub-regional centre of Radom. In contrast, the peripheral towns are located on the borders of the region, in places where the impact of Warsaw and the sub-regional centres tend to be limited.

Table 2

Selected socioeconomic features of the analysed groups of towns (2014)

\begin{tabular}{|l|r|r|}
\hline \multicolumn{1}{|c|}{ Features } & $\begin{array}{c}\text { Agglomerated } \\
\text { towns }\end{array}$ & $\begin{array}{c}\text { Peripheral } \\
\text { towns }\end{array}$ \\
\hline Mean number of inhabitants & 7114 & 4921 \\
Share of the population that is of pre-productive age & 21.9 & 17.2 \\
Share of the population that is of productive age & 63.7 & 63.9 \\
Share of the population that is of post-productive age & 14.4 & 18.9 \\
Entities per 1000 inhabitants of post-productive age & 188.2 & 174.2 \\
Balance between arrivals and departures for work (2006) & -297 & 231 \\
\hline
\end{tabular}

Source: BDL GUS (Local Data Bank of the Central Statistical Office)

The analysis of the changes in population over the 1970-2014 period shows that the towns in both categories have in fact been experiencing overall increases in population, albeit at different rates and with peaks in different periods (Fig. 2). Up to the end of the communist period, there was only a small increase in population (20 people per year) in the agglomerated towns. It was only in the 1990s that a more marked increase in the numbers of the inhabitants (up to 65 per year) took place, only to accelerate, in the most recent decade, up to 145 people per year. Demographic processes assumed this kind of course when the systemic transformation put an end to the policy of restricting the new registration in the towns and cities of the Warsaw agglomeration, and when the post-1989 suburbanisation process gathered pace. The trend was rather the reverse in the peripheral towns, which developed demographically the most prior to the change of political system, only to experience stagnation followed by a slight downward trend in the subsequent years. The population increase in the peripheral towns reflected a development of the industrial, production and construction activity in the communist era, with these towns attracting the rural population mainly seeking and finding work in professions not requiring a high level of professional qualification.

1) The basic units of Poland's territorial administration (gminas) are divided into rural, urban and urban-rural categories.

2) Units of territorial administration at the second level, taking in part of a region (voivodeship). 


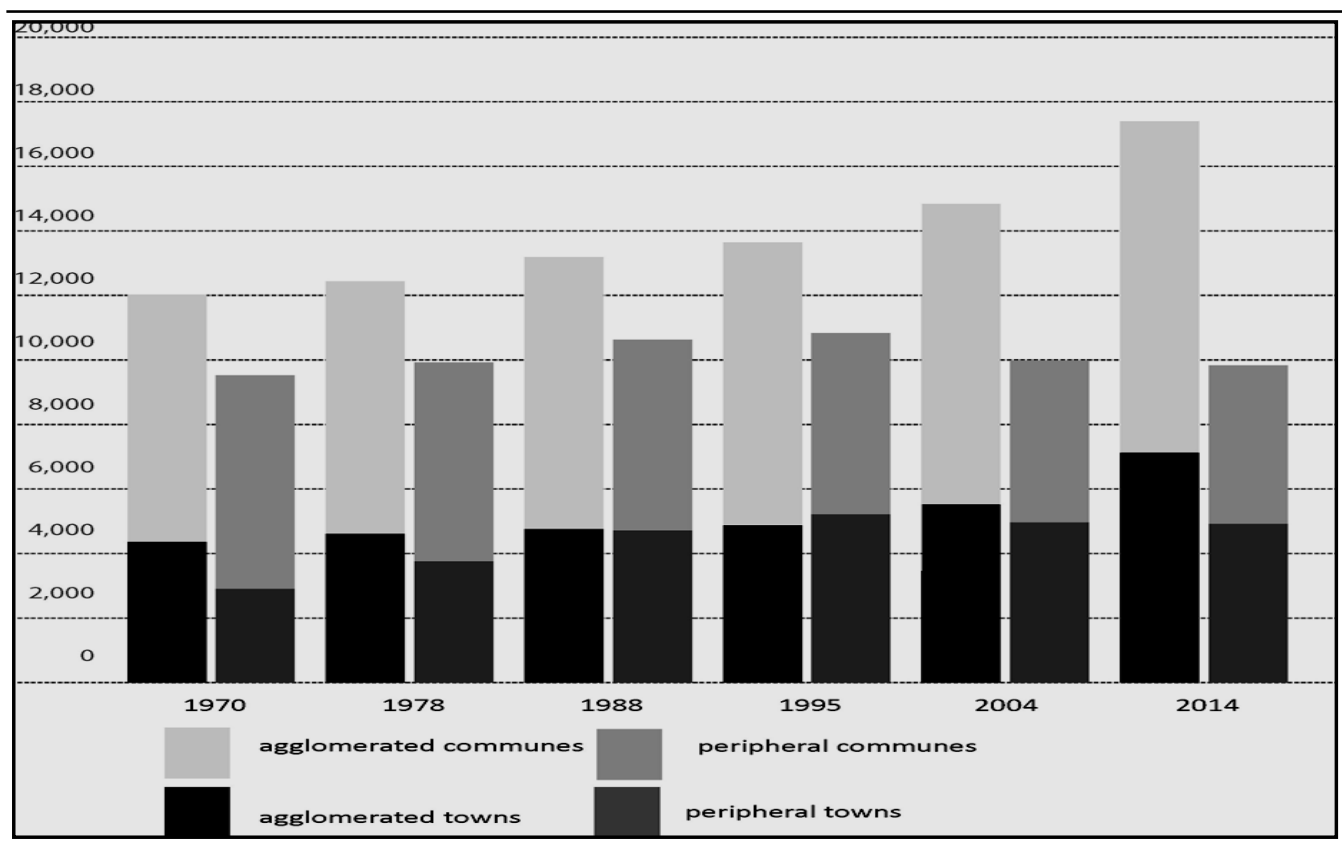

Fig. 2 - Mean numbers of inhabitants in the agglomerated and peripheral towns and in their vicinity, in the period 1970-2014

Source: own research based on the data of the Central Statistical Office

Interesting conclusions are to be drawn from the analyses of population trends in the vicinities of the studied towns. In the case of the agglomerated towns, the whole period 1970-2014 saw the share of the urban inhabitants among all those living in a given urban-rural gmina range between 36 and $41 \%$, i.e. with only a slightly change. This reflected a similar tendency for the new incoming inhabitants to settle in either rural or urban parts. In contrast, the peripheral towns were characterised by an increased in the corresponding figure from $30 \%$ in 1970 to $50 \%$ in 2014.

The processes of the spatial concentration and dispersion of population represent some of the fundamental factors describing regional development trends. It should be borne in mind that the current index for natural growth in Mazovia oscillates around $0 \%$, with migration thus representing the main factor conditioning the spatial differentiation to certain demographic features (Fig. 3). The migration balances for the peripheral towns have been negative for more than 10 years now, while those characterising the agglomerated towns have been positive, for the aforementioned reasons associated with the suburbanisation process.

A significant difference between the towns in the studied categories applies to the age structure of the population (Fig. 4). The agglomerated towns have a higher proportion of their population that is of young (pre-productive) age: more than $4 \%$ higher where the comparison is with the peripheral small towns, and more than 3\% higher than the average for Mazowieckie voivodeship. A location in the immediate vicinity of a large town makes a daily commute to work possible, and - according to research from 2006, about $15 \%$ of the inhabitants of productive age in these towns do indeed commute daily to work - mainly in Warsaw or Radom. The effect is represented by similar living conditions and quality of life for those towns located close to the main centre. In contrast, important migratory outflows take place in the peripheral small towns, first and foremost among young people and women of marriageable age. In 


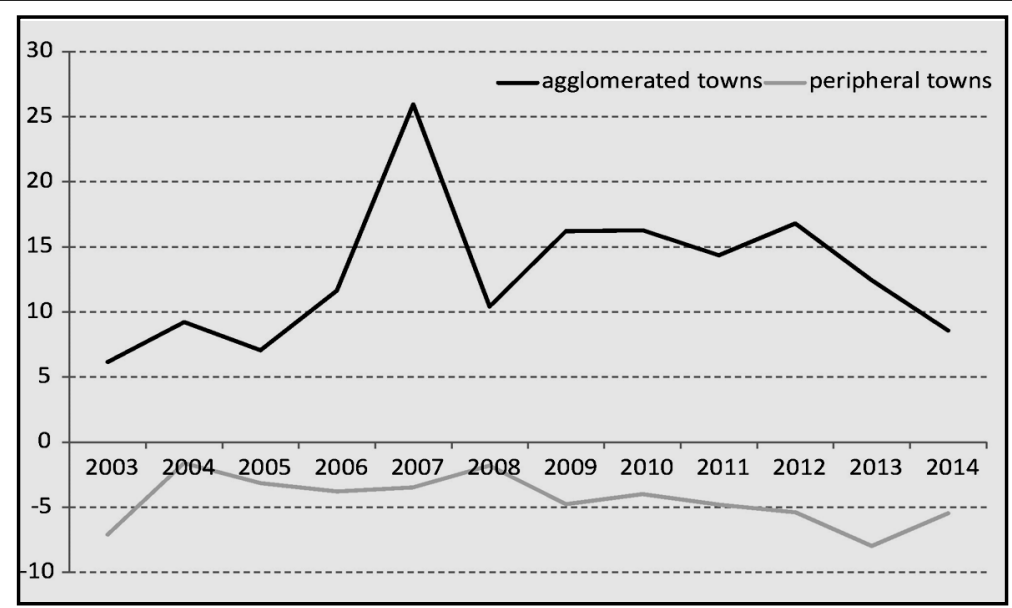

Fig. 3 - Migration balance in the 2003-2014 period (\%)

Source: own research based on the data of the Central Statistical Office

consequence, the peripheral towns under study suffer more from population ageing, with the share of the population made up of people of post-productive age being $4.5 \%$ greater than in the agglomerated towns, while the proportion of the population that is of productive age remains similar. Negative trends related to the demographic structure of peripheral towns first emerged as the systemic transformation began. They were characterised by a marked fall in the share of the population of pre-productive age, with the principal effect of this being an increase in the share of population of post-productive age (from $9 \%$ in 1995 to $19 \%$ in 2014). While the "surplus" of the young over the older inhabitants in peripheral towns stood at around

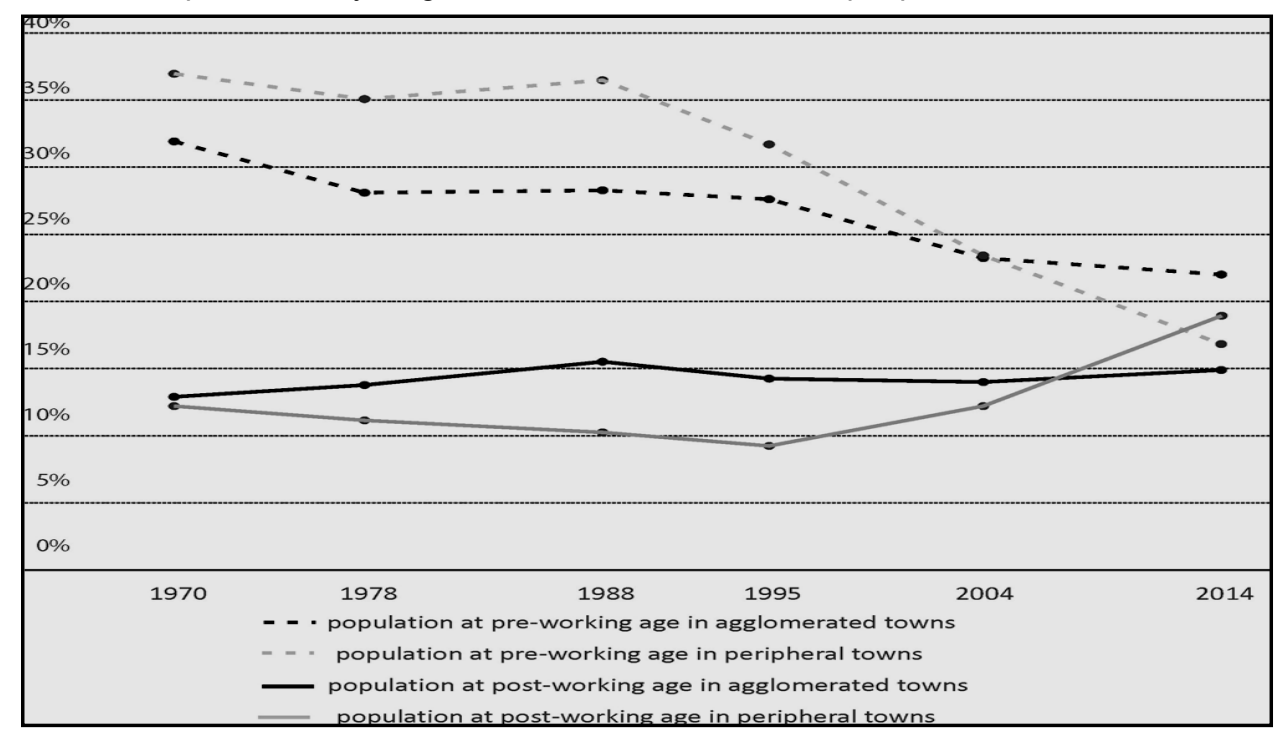

Fig. 4 - Percentage changes in the shares of population accounted for by the different age categories in the agglomerated and peripheral towns

Source: own research based on the data of the Central Statistical Office 
720 people on average in 1970 , there is today a prevalence of 110 people of the elderly over the youth in each town on average. The course of changes was in fact similar in the agglomerated towns, with the surplus of people of pre-productive age over those of post-productive age declining from 1600 on average to 640, even if there was no reversal of the overall trend. The process followed the same course in the rural areas in the immediate vicinity of the towns studied.

These demographic dynamics are reflected in the construction of new housing in both types of small towns (Fig. 5). While the construction of new dwellings in the small towns close to larger cities (and also in their surrounding areas) has experienced a major upturn since $2005^{3}$, this has not been the case in the peripheral towns. The number of housing units constructed annually in these towns has been very limited through the whole period, and it showed a slight downward trend in the past few years. The growing number of housing units constructed in the

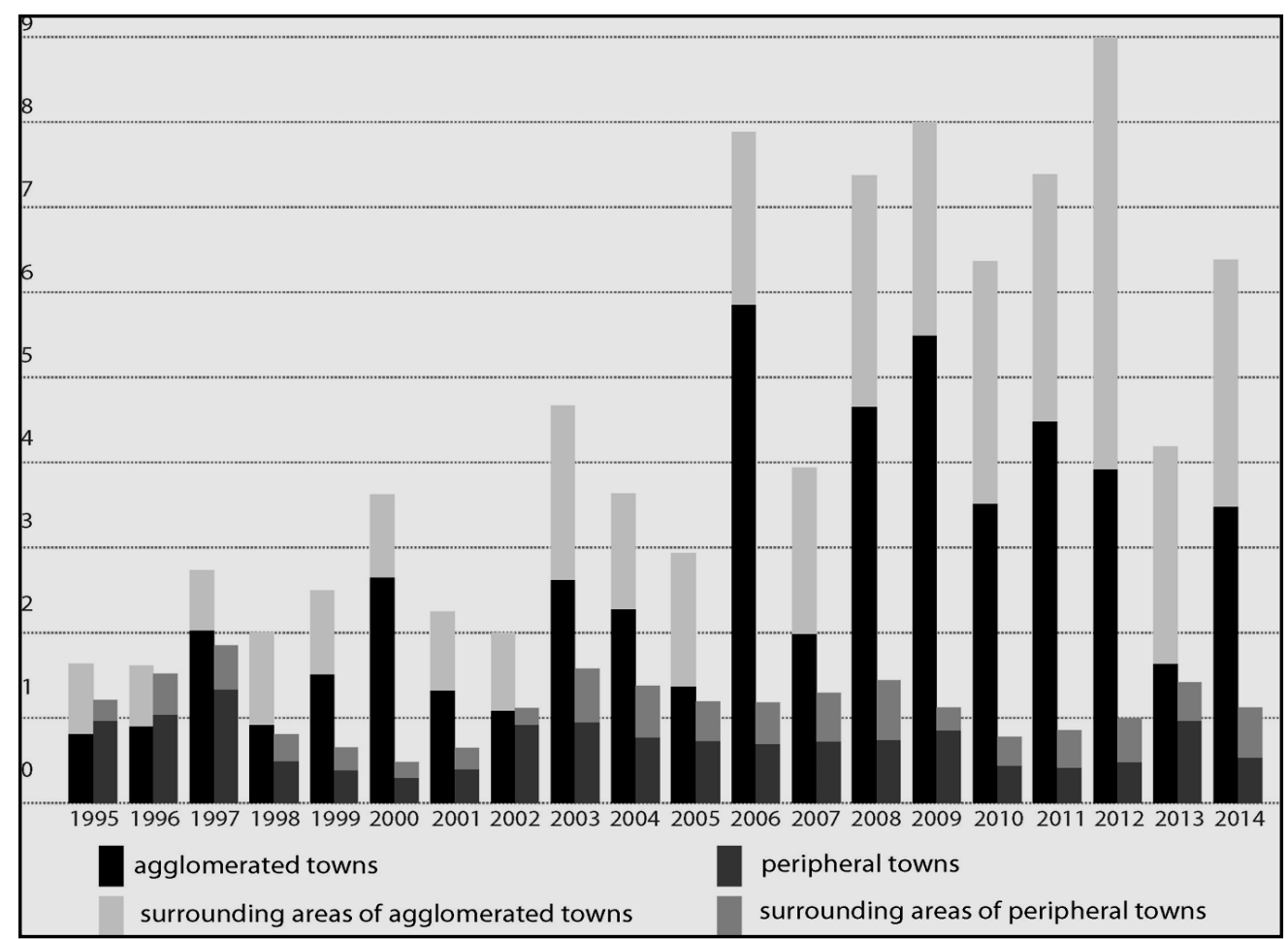

Fig. 5 - Share of newly constructed dwellings in the total housing stock by types of small towns and surrounding areas (1995-2015)

Source: own research based on the data of the Central Statistical Office

areas surrounding the small agglomerated towns indicates, in turn, that the processes of suburbanisation and sprawl involve the largest towns but they are also starting to impact the small towns. However, only those located in the vicinity of larger urban areas are prone to such

3) In 2008-2009, the dynamics for housing construction in the agglomerated towns was of 19 dwellings per 1000 inhabitants. This almost matched the level of construction observed in the suburban municipalities of Warsaw, like Piaseczno and Lesznowola. 
tendencies. The generation of new housing is dominated by individual-level constructions though private developers also support the process in the agglomerated towns. The role of the latter was rather minor through to 2006 (between 1995 and 2006, dwellings constructed by private developers accounted for less than $7 \%$ of all newly built stock); but it has been reinforced in the past decade (between 2006 and 2015, more than $61 \%$ of new dwellings were delivered by developers). It is worth noting that developers are hardly operating in peripheral towns and the areas surrounding them.

Towns located in the vicinity of large agglomerations differ from the peripheral centres in having a greater share of entities active in manufacturing, construction, R\&D sector and market services. In contrast, the latter have a higher share of entities in commerce, transport, education, health and other non-market services. The peripheral centres would also seem to have a rather more balanced structure of business entities than the agglomerated towns. This probably reflects the different role these units from peripheral areas play in regard to the rural areas surrounding them. Besides economic functions, they also serve important social, service-related, commercial and communication functions. It is in the main centres that non-market services are concentrated, along with various manifestations of cultural life. In contrast, in the case of the agglomerated towns, a part of the functions (in healthcare, finance, education and transport) is discharged by the agglomeration centres themselves, especially when it comes to the inhabitants of rural areas.

Interesting conclusions are supplied by the analysis of changes in own income characterising the gminas (local authorities) associated with the agglomerated and peripheral towns. In the early 2000s, the level of this income expressed per inhabitant was actually higher in the peripheral towns under study, mainly as a consequence of receipts from property taxes - which were higher there when expressed per head. However, as the years passed, the gminas in the agglomerations progressed with the construction of a single-family housing and managed to attract more and more better-off people, with the result that gmina's own incomes associated with property tax grew, as did those deriving from income tax levied on natural persons.

Concentrations of selected kinds of business and social activity in the towns were also analysed, in relations to the rural areas surrounding them. A markedly higher concentration was found to characterise the peripheral towns, which constituted important centres servicing the surrounding rural areas (Fig. 6). Hence, these tows concentrated considerably more businesses and services than it would be expected from the number of people they have. In contrast, the agglomerated towns have far lower indices from these points of view, which is to say that the network of the studied social and economic institutions is spread diffusely across the whole territorial unit (town plus rural areas), with further elements of these being supplied by Warsaw and Radom. In certain cases (e.g. those involving libraries and primary schools), the numbers in the studied agglomerated towns are lower than it would be expected from their demographic potential. What it is also noticeable is the steady growth in importance of the small towns studied (be they peripheral or agglomerated), when it comes to what is made increasingly available by the educational and cultural institutions.

The greater significance of small towns, located in peripheral areas as local centres of development, is also confirmed by the analysis of shuttle migrations associated with journeys to work (Fig. 7). Notwithstanding an economic potential more limited than that characterising the agglomerated towns, the peripheral towns are characterised by a positive balance for the journeys to work. According to the 2006 Central Statistical Office data, the balance for journeys to work was positive and it amounted to some 75 people per 1000 of productive age. These values were very much made up for by negative values for the balance concerning the rural areas surrounding these towns, though it cannot be said that the "town-surrounding rural areas" system of commutes to work is closed in its nature, given that there are people who travel greater distances - to sub-regional centres or even to Warsaw. In the case of the agglomerated 


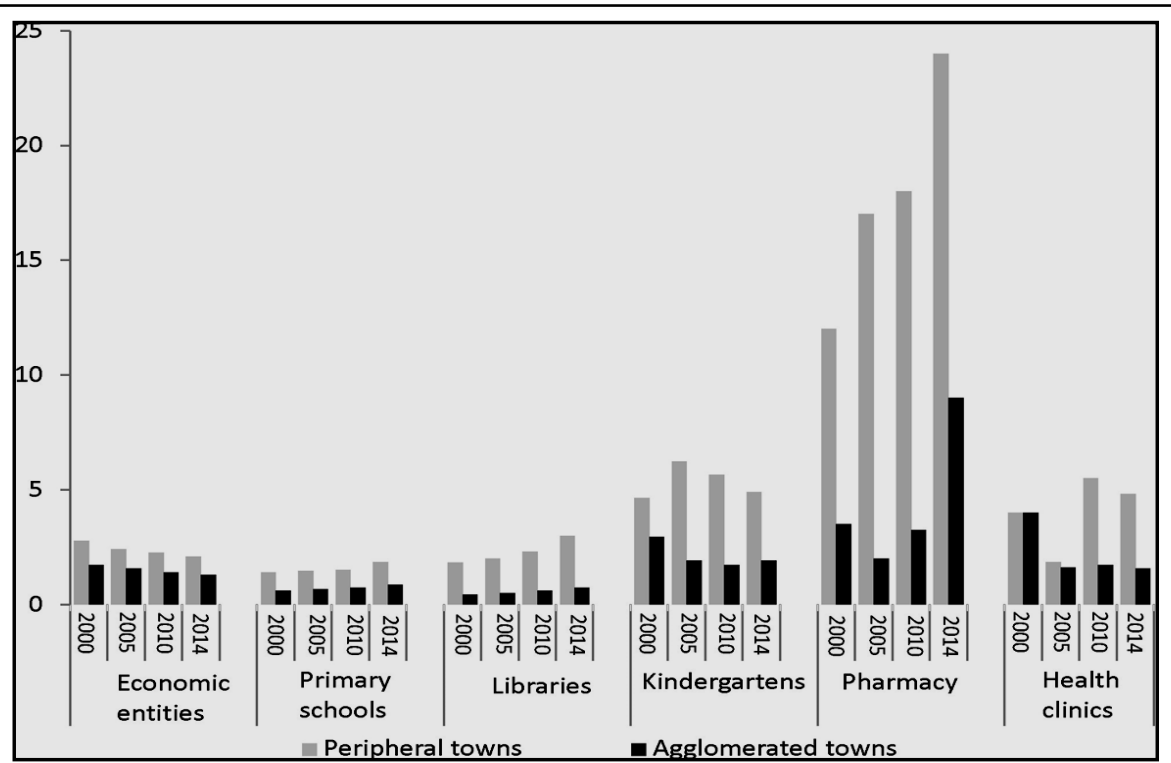

Fig. 6 - Concentration ratio of selected kinds of business and service activity in towns in relation to the surrounding rural areas (communes)

Source: own research based on the data of the Central Statistical Office

towns and the rural areas surrounding them, there were negative balances for travels to work in both considered years. Given the proximity of the very large labour markets represented by Warsaw (in the cases of Ożarów Mazowiecki, Serock, Radzymin and Pilawa), or else Radom (in the case of Skaryszew), the inhabitants of these towns and the rural localities close to them work mainly on these two labour markets. Among all those travelling into work in the agglomerated towns, only every fourth person lived in the rural areas surrounding the latter, which is to say only two-thirds as many as in the case of the peripheral towns.

The content analysis, based on the websites of 10 case studies of small towns, complements the information on the functional structure of these urban units. In particular, it shows the main marketing strategies of the given towns, as well as the particular features they seek to highlight. In general, the functional profiles of small towns in these two categories are quite differentiated. In the group of peripheral towns, the role of the tourism-related and recreation function (including through second homes) was underlined, in Chorzele and Różan above all. These towns are eager to attract new economic entities operating in tourism. In Lipsko, the goal of the "Lipsko Park" project implemented with EU funding was to develop active historical tourism, and to create a comprehensive tourist offer that took in the most valuable natural and anthropogenic resources of Lipsko and the surrounding areas. Nevertheless, the economy in Lipsko remains strongly based on industrial activities, as does that of Łosice. On the other hand, Przysucha is actively pursuing a strategy to strengthen the development of its industrial functions. The 2011 establishment of an Economic Activity Zone also confirms the particular value assigned to this direction of development.

The group of agglomerated small towns exemplify slightly different strategies for development and local marketing. Through their local development strategy and urban renewal programme, Serock and Radzymin attempt first to cater for the needs of the local population, and then to strengthen their role as a local recreation and tourism centre in the Warsaw agglomeration. Pilawa introduces itself as an administrative and commercial centre for the surrounding areas, 
albeit with the majority of local residents commuting to work in Warsaw. Skaryszew highlights the provision of services and support for agriculture; while Ożarów Mazowiecki hosts key enterprises, widely known in Poland, that take advantage of Warsaw's proximity. Finally, Podkowa Leśna, as a garden-town dating back to the 1920s unspoilt by industrial activity, has completely different objectives. Together with the neighbouring towns, Podkowa Leśna is emphasising the strengthening and promotion of a local brand reflecting natural resources, unique architecture and heritage, and the presence and activity of local artists and craftspeople.

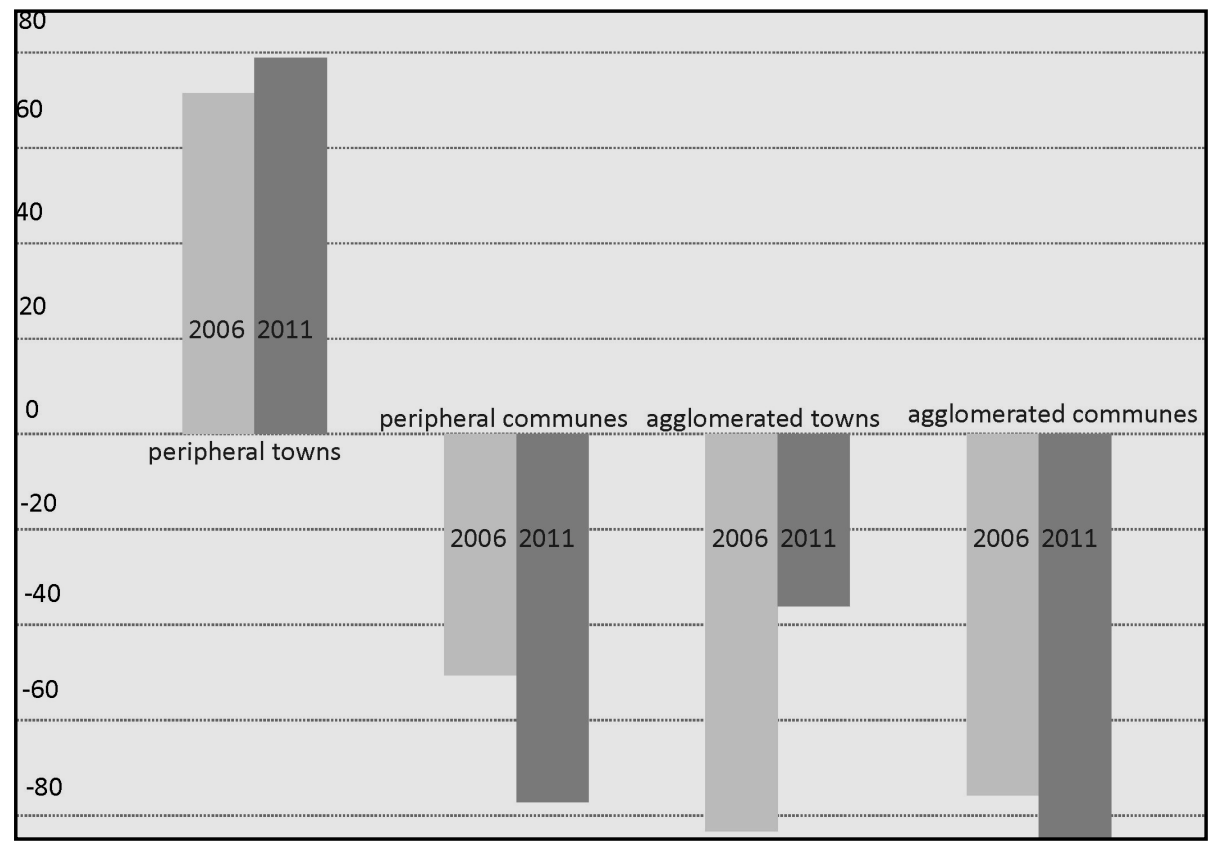

Fig. 7 - Balance between arrivals and departures for work calculated per 1000 inhabitants of productive age in peripheral and agglomerated towns, and the surrounding rural areas, in 2006 and 2011

Source: own research based on the data of the Central Statistical Office

This brief outline of individual case-study small towns revealed the several different strategies being used to build positions and to promote functional specialisations in relation to (peripheral or agglomerated) location, but also on the basis of local resources and heritage.

\section{Conclusions}

The main goal of the paper was to explore and explain the role of small towns in Mazovia region with regard to their location, notably in the proximity of the Warsaw agglomeration or else, in a peripheral location. One of the consequences of geographical location was found to be a varied influence of institutional factors even in the communist era, with this doing most to affect the socio-demographic structure of these two groups of small towns.

The analyses carried out make it clear that small towns located in peripheral areas are characterised by unfavourable demographic processes, up to and including steady depopulation that mainly results from a negative migration balance plus population ageing. These processes began with the systemic transformation, only to gather strength in the 
subsequent years. In turn, the small towns located within the wider surroundings of the agglomerations have been experiencing population growth assuming particular intensity in the last $10+$ years. Thanks to migration inflows - above all involving young families with children these centres continue to manifest a relatively favourable demographic structure.

Like previous studies carried out in the Czech Republic (Vaishar and Zapletalová 2009, Vaishar et al. 2015), this one confirms that small peripheral towns have much more important functions to supply to the rural areas surrounding them than agglomerated towns have. As a high rate of depopulation continues in rural areas, the relative demographic potential of the peripheral towns grows (Fig. 8). They furthermore concentrate different kinds of both service-related and productive activity, the level often being more than twice as high as it would follow from their demographic potential alone. Ultimately, they also often represent the only alternative when it comes to people finding a job - hence the positive balance where travelling to work is concerned. This result partially contradicts findings from the Kaluga region (Savoskul et al. 2014), in which a location on the fringes was directly associated with a process of stagnation in small towns.

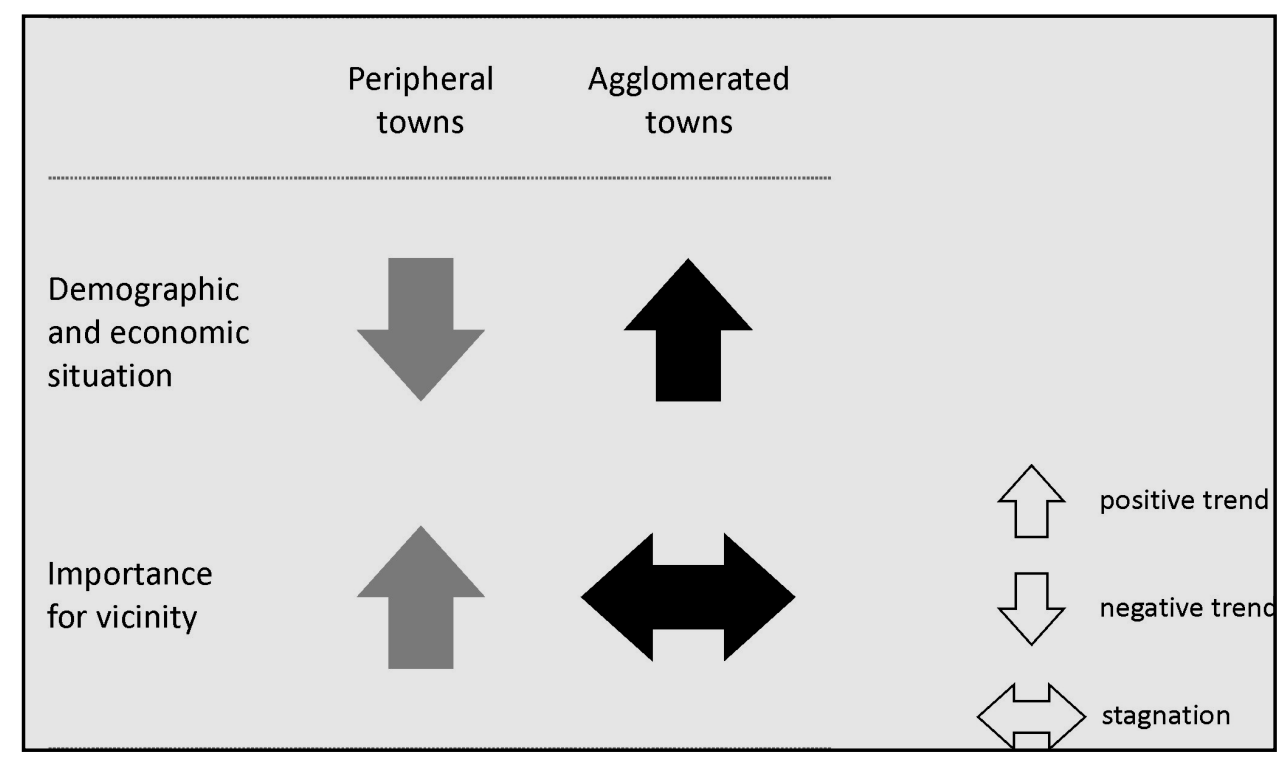

Fig. 8 - Development trends characterising Mazovia's small towns Source: own research

In contrast, the agglomerated small towns are often located in areas with a very evenly distributed settlement network, to the point where they cannot be said to exceed the neighbouring rural areas in population terms (unlike their peripheral counterparts). In addition, the locations of the larger poviat towns, and above all the regional and sub-regional centres, ensure for these only a much more limited ability to compete, when it comes to the functions served in relation to the surrounding areas.

Small towns located peripherally thus serve key functions where the surrounding rural areas are concerned, even though they are losing internal potential at one and the same time. In line with the concept of neoendogenous development, a local system not possessing sufficient potential of its own is not always able to make full use of the existing external conditioning. In other words, in units characterised by lesser internal potential, the effectiveness of use of 
external factors will be more limited than in towns in which the endogenous resources have been more fully built up. This is why a steady weakening of the potential of small towns may ensure a diminishing role for them in the future, and a more and more limited impact on the surrounding rural areas.

The recurrent question concerns how (and in relation to what dynamics) change will be observed in the upcoming years, in the rural areas surrounding small towns. A decline in the agricultural function is to be observed, as there are negative demographic changes in the areas around the peripheral small towns, though some studies have detected suburbanisation and sprawl in areas surrounding agglomerated towns. Such findings encourage further discussion of policies dedicated to small towns, and the need for a more territorial approach that would address the variety of location-related problems and the challenges that small towns face.

\section{References}

BAŃSKI J. (2009), Odrębność obszaru podmiejskiego w kontinuum miejsko-wiejskim [Independence of a suburban area in an urban-rural continuum], Czasopismo Geogr. 80 (4), 210-228.

BAŃSKI J., CZAPIEWSKI K. (2015), A vision of the polycentric development of the Mazovia region in Poland, Geograficky Casopis 67 (4), 301-321.

COURTNEY P., ERRINGTON A. (2000), The Role of Small Towns in the Local Economy and Some Implications for Development Policy, Local Economy 15 (4), 280-301.

DURANTON G., PUGA D. (2005), From sectoral to functional urban specialisation, Journal of Urban Economics 57 (2), 343-370.

ELSASSER H. (1998), Ist eine Kleinstadt mehr als eine kleine Stadt? [ls a small town more than a small town?], in: Munduch E.-M. (ed.), Kleinstädte - Motoren im ländlichen Raum, Tagungsband, Murau, pp. 10-18.

ESPON (2006), The Role of Small and Medium-Sized Towns (SMESTO). Final Report, ESPON, Retrieved from: https://www.espon.eu.

HAN S. S. (2010), Urban expansion in contemporary China: What can we learn from a small town? Land Use Policy 27 (3), 780-787.

HEFFNER K. (2005), Małe miasta $w$ rozwoju obszarów wiejskich [Small towns in the development of rural areas], in: Heffner K. (ed.), Małe miasta a rozwój lokalny i regionalny, Akademia Ekonomiczna, Katowice, pp. 11-34.

HINDERINK J., TITUS M. (2002), Small towns and regional development: Major findings and policy implications from comparative research, Urban Studies 39 (3), 379-391.

JERCZYŃSKI M. (1977), Funkcje i typy funkcjonalne polskich miast [Functions and functional types of Polish towns and cities], in: Krzeczkowska E. (ed.), Statystyczna charakterystyka miast: funkcje dominujące, ZWSiD, Warsaw. 316.

KACHNIARZ T. (1987), Małe miasta [Small towns], Człowiek i Środowisko 11 (3), 281 -

KWIATEK-SOŁTYS A., WIEDERMANN K., MAINET H., EDOUARD J.-C. (2014), The Role of Industry in Satellite Towns of Polish and French Metropolitan Areas - Case Study of Myślenice and Issoire, Prace Komisji Geografii Przemysłu Polskiego Towarzystwa Geograficznego 25, 194- 211.

LAMBE W. (2008), Small Towns, Big ideas. Case Studies in Small Town Community Economic Development, UNC School of Government \& N.C. Rural Economic Development Center, Retrieved from: http://www.iog.unc.edu/programs/cednc/stbi/pdfs/stbi_final.pdf.

LEIMGRUBER W. (1994), Marginality and marginal regions: problems of definition, in: Chang C.-Y. D., Jou S.-C., Lu Y.-Y. (eds.), Marginality and development issues in marginal regions. Proceedings of IGU Study Group Marginalization, Globalization and Regional and Local Responses, National Taiwan University and IGU, Taipei, pp. 1-18.

LAMPRECHT M. (2008), Functional changes in 20th century industrial areas of small towns in central Poland, European Spatial Research and Policy 15 (1), 25-38. 
LIN G. C. S. (1993), Small Town Development in Socialist China: a Functional Analysis, Geoforum 24 (3), 327-338.

MÁLIKOVÁ L., SPIŠIAK P. (2013), Vybrané problémy marginality a periférnosti vidieckych regiónov na Slovensku, Acta Geographica Universitatis Comenianae 57 (1), 51-70.

MONTABONE B. (2013), Périphéries exploitées ou relais indispensables? Les petites villes du département d'Izmir (Turquie) dans le projet métropolitain, Annales de géographie 1 (689), 24-46.

NOVOTNY L., MAZUR M., EGEDY T. (2015), Definition and delimitation of peripheries of Visegrad countries, Studia Obszarów Wiejskich 39, 35-48.

RYDZA E. (ed.), (2006), Rola małych miast w rozwoju obszarów wiejskich [The role of small towns in the development of rural areas], Studia Obszarów Wiejskich 11, IGiPZ PAN, Warszawa.

SATTERTHWAITE D., TACOLI C. (2003), The Urban Part of Rural Development: The role of small and intermediate urban centres in rural and regional development and poverty reduction, IIED, London.

SAVOSKUL M. S., MOZGUNOV N. A., Pivovar G. A. (2014), Social-economic transformation of small towns of the non-Chernozem region (case study of the Kaluga oblast), Moscow University Bulletin. Series 5. Geography 2, 62-67.

SCHMIDT M. (1998), An integrated systemic approach to marginal regions: from definition to development policies, in: Jussila H., Leimgruber W., Majoral R. (eds.), Perception of Marginality: theoretical issues and regional perceptions of marginality, Ashgate Publishing, Aldershot, pp. 45-66.

SZYMAŃSKA D., GRZELAK-KOSTULSKA E. (2005), Małe miasta w Polsce - zmiany ludnościowe i funkcjonalne $w$ drugiej połowie $X X$ wieku [Small towns in Poland-demographic and functional changes in the second half of the 20th century], in: Heffner K. (ed.) Małe miasta a rozwój lokalny i regionalny, Wydawnictwo Uczelniane Akademii Ekonomicznej w Katowicach, Katowice, pp. 59-90.

WOODS M., EDWARDS B., WALKLEY C. (2007), Small and market towns in rural Wales and their hinterlands, Wales Rural Observatory, Retrieved from: http:/l www.walesruralobservatory.org.uk/.

VAISHAR A., ŠŤASTNÁ M., STONAWSKÁ K. (2015), Small towns - engines of rural development in the South-Moravian region (Czechia): an analysis of the demographic development, Acta Universitatis Agriculturae et Silviculturae Mendelianae Brunensis 63 (4), 1395-1405.

VAISHAR A., ZAPLETALOVÁ A. (2009), Small towns as centers of rural micro-regions, European Countryside 1 (2), 70-81.

ZUZAŃSKA-ZYŚKO E. (2005), Economic transformation of small Silesian towns in the years 1990-1999, Geographia Polonica 78(1), 137-149.

Initial submission: 28.06.2016

Revised submission: 13.12 .2016

Final acceptance: 19.12.2016

Correspondence: Institute of Geography and Spatial Organization, Polish Academy of Sciences, Twarda 51/55, 00-818 Warsaw, Poland

Email: jbanski@twarda.pan.pl 
